\title{
Life history events of eelgrass Zostera marina L. populations across gradients of latitude and temperature
}

\author{
S. E. Blok ${ }^{1}$, B. Olesen ${ }^{2}$, D. Krause-Jensen ${ }^{3,4, *}$ \\ ${ }^{1}$ Institute for Biodiversity and Ecosystem Dynamics, University of Amsterdam, Science Park 904, 1098 XH Amsterdam, The Netherlands \\ ${ }^{2}$ Department of Bioscience, Building 1135, Aarhus University, Ole Worms Allé 1, 8000 Aarhus C, Denmark \\ ${ }^{3}$ Department of Bioscience, Aarhus University, Vejlsøvej 25, 8600 Silkeborg, Denmark \\ ${ }^{4}$ Arctic Research Centre, Building 1540, Aarhus University, Ny Munkegade 114, 8000 Aarhus C, Denmark
}

\begin{abstract}
The wide distribution range of eelgrass Zostera marina L. encompasses a broad temperature gradient potentially affecting the timing of life history events (phenology), which may also change with global warming. We explored the temperature dependence of eelgrass phenology by analysing published studies reporting the timing of in situ flowering, seed maturation and seedling emergence across a range of latitude $\left(26.8-56.8^{\circ} \mathrm{N}\right)$ and annual mean air temperature $\left(6.4-23.7^{\circ} \mathrm{C}\right)$. The timing of events changed significantly along the latitude and temperature gradients, being delayed towards northern, colder locations. On average, an increase in annual mean temperature by $1^{\circ} \mathrm{C}$ advanced the formation of flowering shoots by $12 \mathrm{~d}$ and the maturation of seeds by $10.8 \mathrm{~d}$. Seedlings from warmer locations tended to emerge in autumn, whereas coldwater seedlings did not appear until late winter or early spring resulting in an overall advancement of $9.7 \mathrm{~d}$ per $1^{\circ} \mathrm{C}$ increase in annual temperature. The mean monthly temperature associated with specific life history events showed the strongest temperature specificity for maturation of seeds (range $13.5-20.2^{\circ} \mathrm{C}$ ) and largest variability for the emergence of seedlings (range -1 to $20.2^{\circ} \mathrm{C}$ ). Overall, increased latitude resulted in lower temperature thresholds for flowering, seed maturation and emergence of seedlings, indicating that such thresholds are subject to local adaptation or acclimation rather than being universal across the distribution range. Using a time-forspace approach, our results suggest that future warming will result in advanced timing of life history events of eelgrass and increased capacity for sexual reproduction at northern latitudes.
\end{abstract}

KEY WORDS: Zostera marina $\cdot$ Phenology $\cdot$ Seasonality $\cdot$ Temperature $\cdot$ Warming $\cdot$ Latitude Flowering $\cdot$ Seeds $\cdot$ Seedling

\section{INTRODUCTION}

Eelgrass Zostera marina L. fulfils important roles as an ecosystem engineer in estuarine and coastal waters. This submerged plant creates shelter for ecologically and economically important faunal species, enhances biodiversity, contributes to sediment stability, carbon and nutrient storage, and improves water clarity (Gutiérrez et al. 2011, Duarte et al. 2013). Eelgrass is the most widely dis-

\footnotetext{
${ }^{*}$ Corresponding author: dkj@bios.au.dk
}

tributed seagrass species across a range of latitudes, from warm temperate waters up to northern Arctic regions (den Hartog 1970, Jarvis et al. 2012, Olesen et al. 2015). Distinct life history strategies and a wide tolerance to a range of salinity and temperature conditions allow this seagrass species to exploit areas from brackish estuaries to open oceans over a large geographical range (den Hartog 1970, Walker et al. 2001, Lee et al. 2007a, Nejrup \& Pedersen 2008).

() The authors 2018. Open Access under Creative Commons by Attribution Licence. Use, distribution and reproduction are unrestricted. Authors and original publication must be credited. 
Most eelgrass populations are perennial and depend predominantly on asexual reproduction for meadow maintenance, whereas sexual reproduction provides seeds for fast recovery following biomass reduction and dispersal to new habitats (Den Hartog 1970, Olesen \& Sand-Jensen 1994b, Greve et al. 2005, Lee et al. 2007b). Allocation of energy to sexual reproduction varies greatly within and among geographic locations $(<10-36 \%$ of total shoots), and tends to increase in response to environmental disturbance and nutrient enrichment (Phillips et al. 1983a, Olesen 1999, Cabaço \& Santos 2012, Johnson et al. 2017). Annual populations invest predominantly in sexual reproduction to survive as seeds during unfavourable periods and mainly occur in areas with frequent disturbance (e.g. ice-scour, strong storms or bird grazing) (Robertson \& Mann 1984, van Lent \& Verschuure 1994) or thermal stress causing a complete loss of biomass (Meling-López \& IbarraObando 1999, Kim et al. 2014). As yet, there is no clear evidence for genetic differences between annual and perennial populations (Keddy \& Patriquin 1978, Gagnon et al. 1980, Ferber et al. 2008), suggesting large phenotypic plasticity in allocation of energy to sexual versus clonal reproduction even within short geographical distances (Keddy \& Patriquin 1978, Jarvis et al. 2012, Kim et al. 2014). Hence, no life history strategy seems to provide a superior survival mechanism at a given latitude.

The seasonal timing and duration of life history events also varies across eelgrass populations. For example, in the Gulf of California, at the southern distribution limit of eelgrass, seedlings emerge in late autumn and complete their life cycle in mid-spring in order to survive the less favourable hot summer season as seeds (Santamaría-Gallegos et al. 2000). These populations have an annual reproductive strategy and complete their life cycle within a few months. In more northern populations, seedlings may appear during spring and persist as mature plants for several years through clonal growth. Flowering does not occur until after at least 1 yr of growth, and seeds remain dormant during the cold winter months (Keddy \& Patriquin 1978, van Lent \& Verschuure 1994). The timing of reproductive phases in plants is strongly influenced by climate, with temperature considered the most important controlling factor in temperate and subarctic regions, which implies a strong effect of latitudinal position on phenology (Badeck et al. 2004, Forrest \& Miller-Rushing 2010, Baskin \& Baskin 2014). Since the energy of the sun drives seasonal and latitudinal temperature gradients, photoperiod ultimately plays a role in any temperature-related changes in phenology along latitudinal gradients (Hut et al. 2013). While photoperiod is also identified as a common proximate driver of latitudinal changes in seasonal phenology of insects and terrestrial plants (Badeck et al. 2004, Hut et al. 2013), there is no evidence of such relationships for seagrasses except regarding the circadian reproductive phenology of Thalassia testudinum (van Tussenbroek et al. 2009). The newly published eelgrass genome revealed that eelgrass lacks the phytochrome $\mathrm{C}$ gene (PHYC) that is linked to photoperiodic control of flowering in most plants, suggesting that timing of eelgrass flowering is more controlled by temperature (Olsen et al. 2016).

In eelgrass, the timing of flower development and seed formation occurs increasingly later towards the north along the Pacific $\left(33-56^{\circ} \mathrm{N}\right)$ and Atlantic (35$45^{\circ} \mathrm{N}$ ) coasts of North America (Phillips et al. 1983b). However, no clear relationships between temperature and the timing of the different reproductive phases were observed among the 6 populations studied by Phillips et al. (1983b), and the authors suggested that eelgrass might be adapted to the different temperature regimes across the latitudinal gradient. Another observational study at 4 locations along the west Atlantic coast $\left(35-44^{\circ} \mathrm{N}\right)$ showed a similar delay in the flowering periodicity towards the north, but the reproductive stages occurred at similar temperatures, indicating that the same lower threshold temperatures initiate specific life history events across latitudes (Silberhorn et al. 1983).

Eelgrass populations occur at high latitudes up to subarctic Greenland (64.5 ${ }^{\circ}$, Olesen et al. 2015) and northern Norway $\left(69.8^{\circ} \mathrm{N}\right.$, Olsen et al. 2013) where water temperatures barely reach the threshold temperature of $15^{\circ} \mathrm{C}$ suggested to initiate anthesis (Setchell 1929, Silberhorn et al. 1983). However, flowers and mature seeds have been observed in subarctic Greenland, although sexual reproduction is presumably constrained by short growing seasons and low temperatures (Olesen et al. 2015). In addition to flowering, seedling recruitment is another important life cycle stage for which phenology may change with latitude. Temperature has a strong influence on seed germination, and seedling emergence often shows an obvious seasonal pattern under natural conditions, but there is a lack of studies comparing its timing among geographical locations (Probert \& Brenchley 1999, Orth et al. 2000). Hence, more information on the timing of the suite of eelgrass life history events across the distribution range is needed to evaluate to what extent temperature changes associated with latitude influence the reproductive phenology of eelgrass. 
In this study, we aimed to identify how the timing of life history events and reproductive patterns of eelgrass change along gradients in latitude, temperature and photoperiod, with potential temperature controls being relevant in the context of climate warming. The hypothesis was that the timing of life history events is delayed at northern colder locations relative to southern warmer locations. Secondly, we hypothesised that universal threshold temperatures initiate the timing of specific life history events of eelgrass across the distribution range. The hypotheses were tested through a compilation and analysis of studies reporting in situ flowering, seed maturation and germination of seedlings to assess differences in timing across latitude and temperature.

\section{MATERIALS AND METHODS}

\section{Data collection}

We searched the scientific literature using the following terms 'eelgrass OR Zostera marina' AND 'temperature OR latitude' AND 'flowering OR germination' in Web of Science on 24 August 2016. This resulted in 58 records, which were checked for relevance in relation to our research questions. Additional literature (49 studies) was found by cross-referencing. We identified and included a total of 30 studies that described the life history events of eelgrass (Table 1, Fig. 1). The eelgrass populations of the studies occurred in shallow waters (i.e. 0 to $3 \mathrm{~m}$ depth) from across the northern latitude ranging from 26.8 to $56.8^{\circ} \mathrm{N}$ (Fig. 1), and at mean annual air temperatures ranging from 6.4 to $23.7^{\circ} \mathrm{C}$ (Table 1). While the compilation encompasses populations from a large latitudinal range, it does not include the northernmost edge, where no studies have addressed phenology with sufficient detail.

The life history events of eelgrass such as emergence of seedlings, flowering and seed maturation occur year-round across latitudes. To extract timepoint data of life history events from eelgrass populations, the following sequence of steps was performed. First, we checked whether a life history event was linked to an exact date described in the methods or results that thereafter was used as a timepoint. Instead of an exact date, often a whole month was given as a time-point. To use such data, the middle day of that month was used as a time-point. Lastly, the time-point was occasionally specified by naming the period of the month, such as the beginning or the end of the month. In these cases, the middle of the first or last week of the month was used as a time-point. This accounts for the emergence of seedlings, the initiation, peak and termination of the flowering period and the seed maturation.

Secondly, data were extracted from graphs that represented a variable (e.g. number of seedlings) characterising a certain life stage of eelgrass on the $y$-axis and time on the $x$-axis. If not described in the text, the date was extracted from these graphs using GraphClick 2 (version 3.0.3). The time-point that corresponded with the first observation of flowering and emergence of seedlings, respectively, was used as data. All time-point data are presented as day of the year (DOY).

\section{Eelgrass life history events}

During the reproductive stage, eelgrass undergoes several life cycle events such as flower development, pollen release, pollination, seed production, seed dispersal, seed germination and seedling emergence. This study focused on the flowering period, seed maturation and seedling emergence. We extracted information on the timing of the start, the peak and the end of the flowering season, the timing of the start and peak of seed maturation and the timing of emergence of seedlings. Some studies described multiple stages of flower and seed development, from which the specific reproductive stage and timepoint could be extracted. However, most often the reproductive stage was described by the presence of reproductive shoots as recognized by macroscopic flower structures. In this case, the earliest observation of reproductive shoots was used as a time-point related to the start of the flowering period, and the time-point of peak flowering represented the time of maximum number of reproductive shoots.

The peak of mature seeds was mentioned in several studies. However, most information on mature seeds came from studies that involved eelgrass germination experiments where seeds were collected from the field. These studies did specify if there was a peak in the presence of mature seeds at that time-point; however, the goal was often to collect a large amount of seeds for the experiment. Therefore, it was assumed that the collectors of the seeds chose a time-point where the number of mature seeds was at a maximum. Hence, the collection date of the seeds was used as a time-point for the peak of mature seeds.

The date of seedling emergence was extracted either directly from the text of the compiled studies or from graphs representing the number of shoots or the number of seedlings against time. In the case of an 
Table 1. Studies included in the analysis of timing of eelgrass Zostera marina flowering, seed formation and seedling emergence along a gradient of latitude and annual mean temperature. Some studies contained data from several locations. For studies with no information on sampling frequency (unknown), the date of observation of a specific event was given. Mean temperature (temp.) represents monthly mean air temperature extracted from www.worldclim.org (Hijmans et al. 2005) and averaged over a 30 yr period (1971-2000)

\begin{tabular}{|c|c|c|c|c|c|}
\hline $\begin{array}{l}\text { Region } \\
\text { Country }\end{array}$ & $\begin{array}{l}\text { Sampling } \\
\text { years }\end{array}$ & $\begin{array}{l}\text { Latitude } \\
\left({ }^{\circ} \mathrm{N}\right)\end{array}$ & $\begin{array}{c}\text { Mean temp. } \\
\left({ }^{\circ} \mathrm{C}\right)\end{array}$ & $\begin{array}{l}\text { Sampling } \\
\text { frequency }\end{array}$ & Reference \\
\hline \multicolumn{6}{|l|}{ Northeast Pacific } \\
\hline Washington (USA) & $1974-1976$ & 46.6 & 9.9 & Monthly & Phillips et al. (1983a) \\
\hline Oregon (USA) & 2004-2006 & 44.4 & 11 & Every 2 mo & Boese et al. (2009) \\
\hline Mexico & 1998 & 31.8 & 16.5 & Monthly & Cabello-Pasini et al. (2002) \\
\hline Mexico & 1987 & 30.5 & 19 & Monthly & Poumian-Tapia \& Ibarra-Obando (1999) \\
\hline Mexico & $1997-1998$ & 29.2 & 23.1 & Monthly & Meling-López \& Ibarra-Obando (1999) \\
\hline Washington (USA) & $1974-1976$ & 29.1 & 23.1 & Monthly & Phillips et al. (1983a) \\
\hline Mexico & 1980 & 29 & 23.2 & Seed collection & McMillan (1983) \\
\hline Mexico & $1997-1998$ & 29 & 23.2 & Monthly & Meling-López \& Ibarra-Obando (1999) \\
\hline Mexico & $1977-1980$ & 28.8 & 23.7 & Unknown & Phillips \& Backman (1983) \\
\hline Mexico & $1994-1995$ & 26.8 & 21.7 & Every 3 wk & Santamaría-Gallegos et al. (2000) \\
\hline \multicolumn{6}{|l|}{ Northeast Atlantic } \\
\hline Denmark & $1990-1991$ & 56.8 & 7.7 & Monthly & Olesen \& Sand-Jensen (1994a) \\
\hline Denmark & 2001 & 55.5 & 8.1 & Monthly & Greve et al. (2005) \\
\hline The Netherlands & 1977 & 51.8 & 9.9 & Bi-monthly & de Cock (1981) \\
\hline The Netherlands and UK & 1989 & 51.7 & 9.9 & Seed collection & van Lent \& Verschnure (1995) \\
\hline The Netherlands & 1977 & 51.5 & 10 & Bi-monthly & de Cock (1981) \\
\hline The Netherlands & 1983 & 51.5 & 10 & Bi-monthly & Hootsmans et al. (1987) \\
\hline \multirow[t]{2}{*}{ The Netherlands and UK } & 1989 & 51.5 & 10 & Seed collection & van Lent \& Verschnure (1995) \\
\hline & & 48.8 & 11.2 & & \\
\hline \multicolumn{6}{|l|}{ Northwest Pacific } \\
\hline Japan & 2005 & 39.1 & 11.3 & Seed collection & Yamaki \& Ogawa (2009) \\
\hline China & 2009 & 37.4 & 11.7 & Monthly & Zhang et al. (2016) \\
\hline China & 2013 & 37.2 & 11.7 & Bi-monthly & Wang et al. (2016) \\
\hline China & 2009 & 37 & 11.8 & Seed collection & Pan et al. (2011) \\
\hline China & 2010 & 37 & 11.8 & Seed collection & Pan et al. (2012) \\
\hline Japan & 2005 & 35.2 & 15.5 & Seed collection & Yamaki \& Ogawa (2009) \\
\hline South Korea & $2008-2009$ & 35.1 & 14.2 & Monthly & Kim et al. (2014) \\
\hline \multirow[t]{2}{*}{ South Korea } & 2005 & 35.1 & 14.2 & Seed collection & Park \& Lee (2007) \\
\hline & & 34.8 & 14.4 & & \\
\hline Japan & 2004 & 34.3 & 16.2 & Bi-monthly & Morita et al. (2007) \\
\hline \multicolumn{6}{|l|}{ Northwest Atlantic } \\
\hline Nova Scotia (Canada) & $1975-1976$ & 44.7 & 6.4 & Bi-monthly & Keddy \& Patriquin (1978) \\
\hline Nova Scotia (Canada) & 1980 & 44.7 & 6.4 & Monthly & Robertson \& Mann (1984) \\
\hline Nova Scotia (Canada) & $1975-1977$ & 43.8 & 6.7 & Unknown & Keddy (1987) \\
\hline New York (USA) & 1975 & 40.7 & 11.4 & Weekly & Churchill \& Riner (1978) \\
\hline Virginia (USA) & 1980 & 37.5 & 14.6 & Weekly & Silberhorn et al. (1983) \\
\hline Virginia (USA) & 2008 & 37.3 & 14.9 & Seed collection & Jarvis \& Moore (2015) \\
\hline Virginia (USA) & 1978 & 37.3 & 14.8 & Seed collection & Orth \& Moore (1983) \\
\hline Virginia (USA) & 1980 & 37.3 & 14.8 & Weekly & Silberhorn et al. (1983) \\
\hline North Carolina (USA) & $2007-2008$ & 34.7 & 17.1 & Monthly & Jarvis et al. (2012) \\
\hline
\end{tabular}

annual population, the first shoots observed were noted as a time-point for the emergence of seedlings. This approach could not be used for perennial populations, since shoots are present all year round. Because the period of seedling emergence from seeds released in late summer/autumn extended beyond 1 January of the following year, the time-point data (DOY) were adjusted so that the dates of onset would increase continuously, by adding 365 to the values of DOY after 31 December.

\section{Latitude, temperature and photoperiod}

The latitudes of the study locations were obtained directly from the text or, alternatively approximated from Google Maps based on descriptions of the study area. Air temperature data were extracted from www.worldclim.org (Hijmans et al. 2005) as monthly temperature data averaged for a $30 \mathrm{yr}$ period (1970-2000) for each study location (Table 1). Long-term temperature averages were used rather 


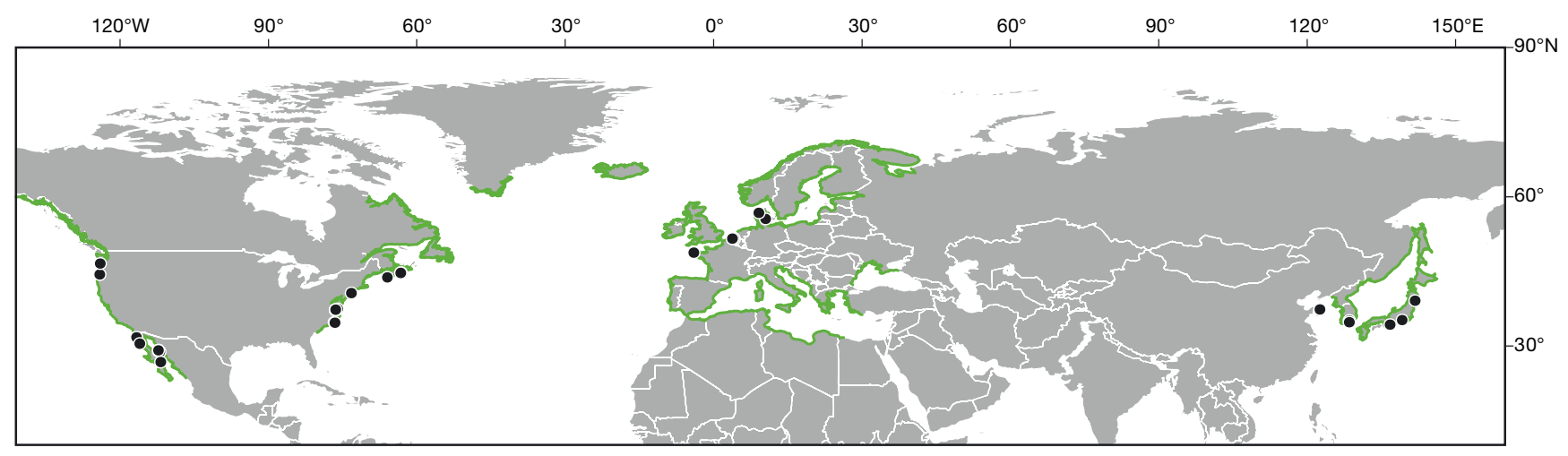

Fig. 1. Locations of Zostera marina populations included in this study. Green outlines show the approximate global distribution of Zostera marina based on Moore \& Short (2006)

than data for specific years, as we aimed to establish as general and robust relationships as possible along the latitudinal gradient while avoiding effects of short-term temperature variability at specific sites. The time-points of each life history event were coupled to the mean monthly temperature of the month of observation as well as to the mean annual temperature. Air temperature is considered to be a good proxy for water temperature due to the equilibrium between surface water and atmosphere from heat exchange, and also because the studies used for this review encompassed shallow study sites (0-3 m) (Cabello-Pasini et al. 2003, Lee et al. 2006). As the proxies are not exact representations of the temperatures experienced by the seagrass meadows, the identified temperature thresholds along the latitudinal gradient should be considered relative rather than precise. Similar precautions would have been necessary had we instead used satellite-based sea surface temperature (SST) data (van Wynsberge et al. 2017).

Data on photoperiod were extracted for the month of the various life history events at the latitude representing each of the sites, using the link: http://astro. unl.edu/classaction/animations/coordsmotion/day lighthoursexplorer.html

\section{Data analysis}

In order to test the hypothesis that the timing of eelgrass life history events depends on latitude and temperature, we explored the relationships and conducted linear regression analysis of each life history event as a function of latitude and mean annual temperature, respectively. Temperature and latitude were highly correlated (Pearson's $\mathrm{r}=-0.87$ ), so to avoid multicollinearity, no multiple regressions were performed. We further explored temperature thresholds of specific life history events by quantifying the temperature range of the events, i.e. the temperature associated with the month of the event, to address the degree of temperature sensitivity of the events. We also explored, through linear regression analysis, whether the temperature thresholds of the events are universal or differ across the eelgrass distribution range. Moreover, in parallel to the analysis of temperature thresholds of life history events, we also explored potential photoperiod thresholds of the events using similar methods. All statistical analyses were performed using RStudio (Version 0.99.489).

The limited dataset does not allow us to resolve the effects of temporal trends in temperature. Instead, we use the established relationships between phenology and temperature to identify the relative change in phenology with temperature and use this in a space-for-time approach to suggest how phenology may respond to warming.

\section{RESULTS}

\section{Flowering}

The timing of the start of the flowering period (mean \pm SE: $102.7 \pm 12.9$ DOY) changed significantly across latitude $\left(F_{1,24}=39.02, p<0.001\right.$; Fig. 2a, Table 2) and with the associated mean annual temperature $\left(F_{1,23}=40.36, \mathrm{p}<0.001\right.$; Fig. $\left.2 \mathrm{~b}\right)$. The timing of the flowering peak $(147.7 \pm 11.2 \mathrm{DOY})$ also showed a significant relationship with latitude $\left(F_{1,21}=26.61\right.$, $\mathrm{p}<0.001$; Fig. 2c) and mean annual temperature $\left(F_{1,20}=27.12, \mathrm{p}<0.001\right.$; Fig. $2 \mathrm{~d}$, Table 2$)$. Accordingly, the start and peak of flowering occurred earlier in the year at the lowest latitudes (e.g. January and 

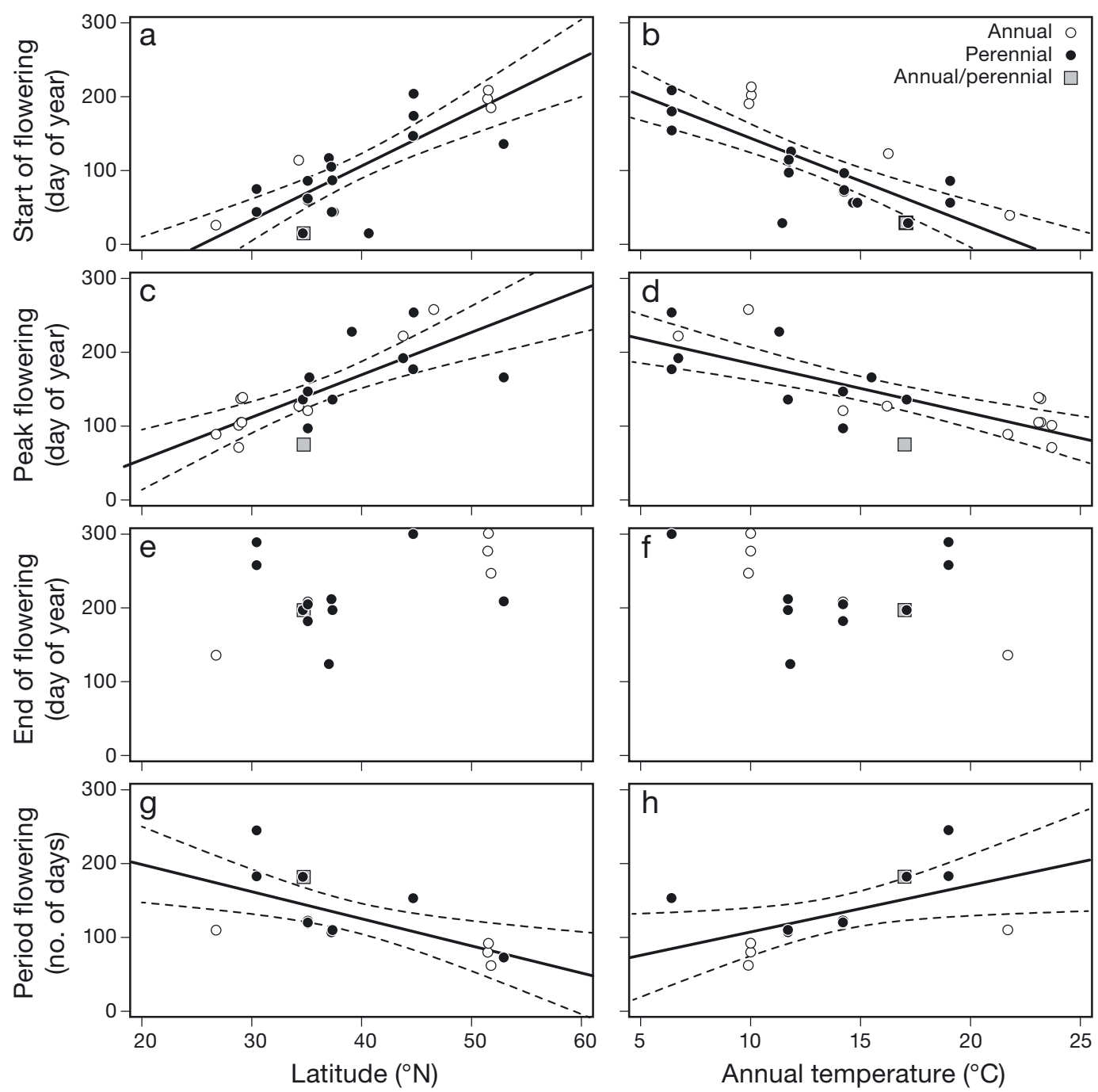

Fig. 2. Timing of the $(\mathrm{a}, \mathrm{b}) \mathrm{start},(\mathrm{c}, \mathrm{d})$ peak, $(\mathrm{e}, \mathrm{f})$ end and $(\mathrm{g}, \mathrm{h})$ duration of the flowering period in Zostera marina meadows as a function of latitude (panels $\mathrm{a}, \mathrm{c}, \mathrm{e}, \mathrm{g}$ ) and associated annual mean air temperature (panels b,d,f,h). Annual, perennial and mixed populations are marked with different symbols to show that in spite of differing reproductive strategies, they follow the same general relationships between phenology and latitude/temperature. The solid lines indicate a significant linear regression; the dashed lines are the upper and lower $95 \%$ confidence interval. Regression statistics are given in Table 2

Table 2. Comparisons between the effects of latitude and mean annual air temperature on the timing of the dependent variables measured in Zostera marina populations. For each dependent variable, the estimated slope of the regression line with latitude and with mean annual air temperature, respectively, is shown. Number of observations (n), standard error (SE) and coefficient of determination $\left(\mathrm{R}^{2}\right)$ are indicated. DOY: day of the year. Significance levels: ${ }^{*} \mathrm{p}<0.05,{ }^{* *} \mathrm{p}<0.01,{ }^{* * *} \mathrm{p}<0.001$

\begin{tabular}{|c|c|c|c|c|c|c|c|}
\hline \multirow[t]{2}{*}{ Variable } & \multirow[t]{2}{*}{$\mathrm{n}$} & \multicolumn{3}{|c|}{ Latitude $\left({ }^{\circ} \mathrm{N}\right)$} & \multicolumn{3}{|c|}{ Annual temperature $\left({ }^{\circ} \mathrm{C}\right)$} \\
\hline & & Estimate & SE & $\mathrm{R}^{2}$ & Estimate & SE & $\mathrm{R}^{2}$ \\
\hline Start of flowering period (DOY) & 25 & $7.302^{* * *}$ & 1.169 & 0.603 & $-12.250^{* * *}$ & 1.928 & 0.621 \\
\hline Peak of flowering period (DOY) & 21 & $5.754^{* * *}$ & 1.115 & 0.537 & $-6.731^{* * *}$ & 1.292 & 0.554 \\
\hline End of flowering (DOY) & 15 & 3.007 & 1.440 & 0.174 & -5.051 & 3.294 & 0.083 \\
\hline Flowering period (no. of days) & 15 & $-3.676^{* *}$ & 1.154 & 0.379 & $6.321^{*}$ & 2.646 & 0.251 \\
\hline Start of mature seed formation (DOY) & 10 & $9.172^{* * *}$ & 1.647 & 0.750 & $-10.82^{* * *}$ & 1.390 & 0.856 \\
\hline Peak of mature seed formation (DOY) & 16 & $5.650^{* * *}$ & 0.741 & 0.781 & $-9.821^{* * *}$ & 1.073 & 0.838 \\
\hline Start of seedling emergence (DOY) & 18 & $6.826^{* * *}$ & 1.033 & 0.704 & $-9.730^{* * *}$ & 2.180 & 0.513 \\
\hline
\end{tabular}


March at $26.8^{\circ} \mathrm{N}$ ), where mean annual temperatures were highest (up to $23.3^{\circ} \mathrm{C}$ ), and later in the season at higher latitudes (e.g. July and September at $44.7^{\circ} \mathrm{N}$ ), where mean annual temperatures were lowest (down to $6.4^{\circ} \mathrm{C}$ ). The onset of flowering advanced by $7.3 \mathrm{~d}$ per $1^{\circ}$ decrease in latitude and was delayed by $12.3 \mathrm{~d}$ per $1^{\circ} \mathrm{C}$ increase in mean annual temperature (Table 2). The timing of the peak flowering period advanced $5.8 \mathrm{~d}$ per $1^{\circ}$ decrease in latitude and was delayed by $6.7 \mathrm{~d}$ per $1{ }^{\circ} \mathrm{C}$ increase in mean annual temperature (Table 2$)$. The timing of the end $(218.9 \pm$ 12.8 DOY) of the flowering period did not show a significant relationship with latitude or mean annual temperature (Fig. 2e,f). The duration of the flowering period $(128.9 \pm 12.2 \mathrm{~d})$ changed significantly across latitude $\left(F_{1,14}=10.16, \mathrm{p}<0.01\right.$; Fig. $\left.2 \mathrm{~g}\right)$ and across mean annual temperatures $\left(F_{1,13}=5.706, \mathrm{p}<0.05\right.$; Fig. $2 \mathrm{~h}$ ). The flowering period was longer at lower latitudes (e.g. $182 \mathrm{~d}$ at $34.7^{\circ} \mathrm{N}$ ) than at higher latitudes (e.g. $80 \mathrm{~d}$ at $51.5^{\circ} \mathrm{N}$ ), decreasing by $3.7 \mathrm{~d}$ per $1^{\circ}$ increase in latitude.

\section{Seed maturation and seedling emergence}

The timing of the first appearance of mature seeds $(163.0 \pm 17.1 \mathrm{DOY})$ changed significantly across latitudes $\left(F_{1,9}=31.0, \mathrm{p}<0.001\right.$; Fig. $\left.3 \mathrm{a}\right)$ and across associated mean annual temperatures $\left(F_{1,9}=60.59, \mathrm{p}<\right.$ 0.001 ; Fig. 3b). The timing of the peak appearance of mature seeds $(172.9 \pm 12.7$ DOY $)$ also changed significantly across latitude $\left(F_{1,15}=58.14, \mathrm{p}<0.001\right.$; Fig. 3c) and mean annual temperature $\left(F_{1,15}=83.84, \mathrm{p}<\right.$ 0.001; Fig. 3d). Similarly to the flowering events, seeds at lower latitudes started maturing earlier in the year, e.g. the peak of mature seeds occurred in March at $26.8^{\circ} \mathrm{N}$ at a mean annual temperature of $21.7^{\circ} \mathrm{C}$, as compared to late August at $48.8-51.7^{\circ} \mathrm{N}$ at mean annual temperatures of $10-11^{\circ} \mathrm{C}$. The timing of the first appearance of mature seeds advanced $9.2 \mathrm{~d}$ per $1^{\circ}$ decrease in latitude and by $10.8 \mathrm{~d}$ per $1^{\circ} \mathrm{C}$ increase in mean annual temperature (Table 2). The timing of the peak appearance of mature seeds advanced $5.7 \mathrm{~d}$ per $1^{\circ}$ decrease in latitude and by
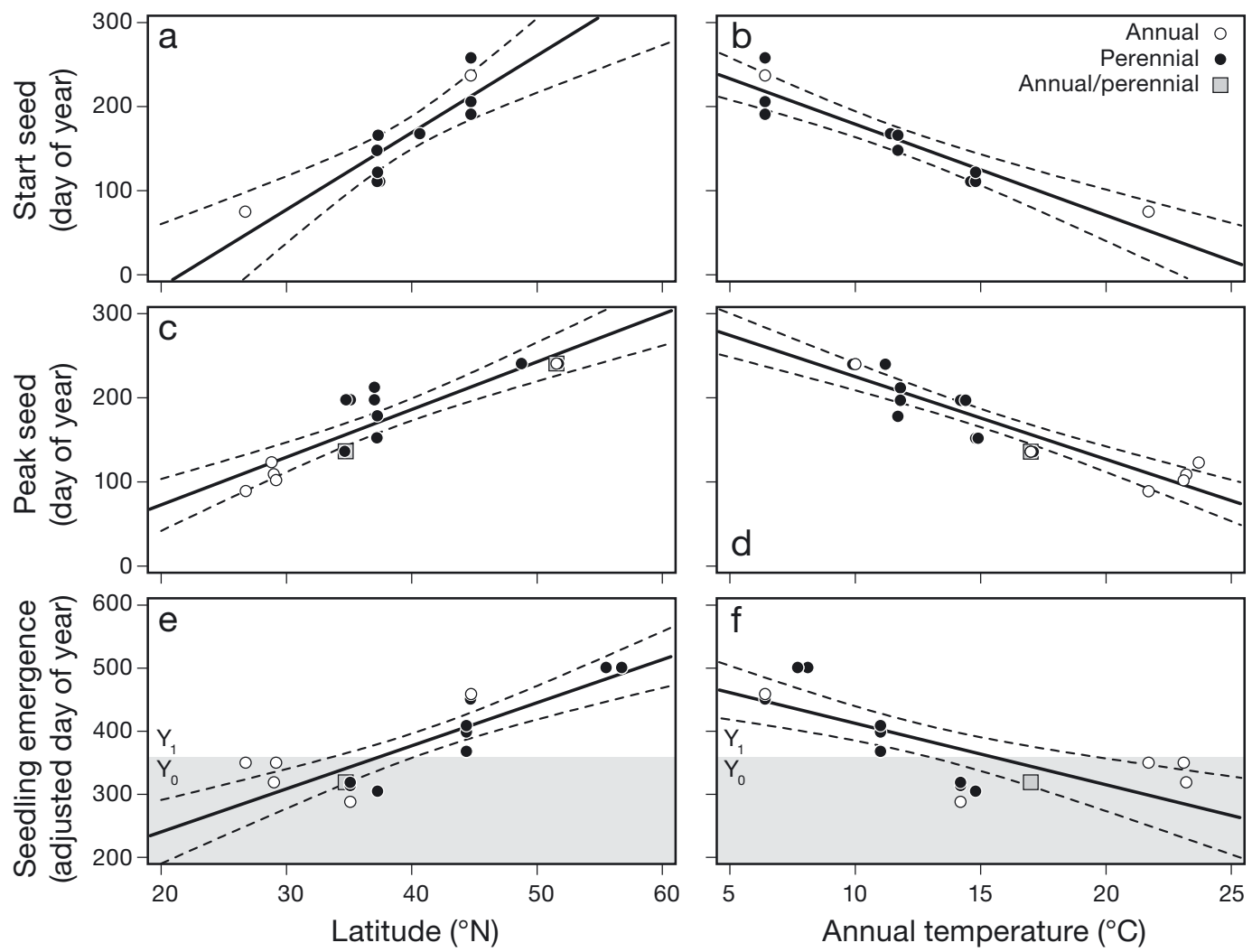

Fig. 3. Timing of the $(\mathrm{a}, \mathrm{b})$ start and $(\mathrm{c}, \mathrm{d})$ peak of mature seed formation and $(\mathrm{e}, \mathrm{f})$ start of the period of seedling emergence in Zostera marina meadows, as a function of latitude (panels a,c,e) and associated annual mean air temperature (panels, b, d,f). For seedling emergence $(\mathrm{e}, \mathrm{f})$ we used an adjusted day of year (DOY) scale encompassing days of 2 yr ( $Y_{0}=$ year of seedling production [gray shade] and $Y_{1}=$ the following year) because some populations already exhibit seedling emergence in the autumn of the year of the seed production while in most cases seedlings emerge the following year. Other details as in Fig. 2 
$9.8 \mathrm{~d}$ per $1^{\circ} \mathrm{C}$ increase in mean annual temperature (Table 2).

The time of emergence of new seedlings $(172.9 \pm$ 29.3 DOY) changed significantly across latitude $\left(F_{1,17}=43.70, \mathrm{p}<0.001\right.$; Fig. 3e $)$ and with mean annual temperature $\left(F_{1,17}=19.92, \mathrm{p}<0.001\right.$; Fig. $\left.3 \mathrm{f}\right)$. At lower latitudes with relatively high mean annual temperatures, seedlings were first observed in late autumn, whereas at higher latitudes with lower mean annual temperatures, seedlings occurred in winter or early spring following seed release in autumn the preceding calendar year (Fig. 3e,f). Accordingly, the timing of the earliest observed seedlings moved forward by $6.8 \mathrm{~d}$ per $1^{\circ}$ decrease in latitude and by $9.7 \mathrm{~d}$ per $1^{\circ} \mathrm{C}$ increase southward (Table 2). The peak and end of the period of seedling emergence were not analysed due to low numbers of observations.

The relationships between timing of events and latitude explains $38-78 \%$ of the variability and the relationship between timing of events and temperature explains $25-86 \%$ of the variability in the data. In both cases, the least variability is explained for the length of the flowering period and most variability is explained for the timing of peak seed formation (Table 2).

\section{Threshold temperature of life cycle events}

The mean monthly temperature associated with the specific life history events, i.e. the threshold temperature of events, generally showed high variability across sites. Hence, the temperature associated with the start, peak and end of flowering across latitudes ranged from -0.3 to $17.7^{\circ} \mathrm{C}, 11.7$ to $24.6^{\circ} \mathrm{C}$ and 9.1 to $26.5^{\circ} \mathrm{C}$, respectively (Table 3 ). The lowest monthly air temperature $\left(-0.3^{\circ} \mathrm{C}\right)$ associated with the occurrence of reproductive shoots was reported from New York,

Table 3. Average, minimum (min) and maximum (max) of monthly temperature associated with various life history events of Zostera marina across its distribution range. The number of observations ( $\mathrm{n}$ ) is indicated

\begin{tabular}{|lcc|}
\hline Life history event & $\begin{array}{c}\text { Temperature }\left({ }^{\circ} \mathrm{C}\right) \\
\text { average }(\min -\max )\end{array}$ & $\mathrm{n}$ \\
\hline Start of flowering period & $10.5(-0.3-17.7)$ & 25 \\
Peak of flowering period & $17.9(11.7-24.6)$ & 19 \\
End of flowering period & $20.5(9.1-26.5)$ & 16 \\
Start of mature seed formation & $16.8(13.5-20.2)$ & 11 \\
Peak of mature seed formation & $20.9(16.7-25.4)$ & 17 \\
Start of seedling emergence & $10.3(-1.0-20.2)$ & 20 \\
\hline
\end{tabular}

USA, in late January and was only slightly lower than the measured local water temperatures $\left(0.5-3^{\circ} \mathrm{C}_{i}\right.$ Churchill \& Riner 1978). The temperature associated with the maturation of seeds was less variable, ranging from $13.5-20.2^{\circ} \mathrm{C}$ for the start of appearance of mature seeds to $16.7-25.4^{\circ} \mathrm{C}$ for the peak occurrence of mature seeds (Table 3 ). The least temperature-specific event was the emergence of seedlings, which occurred at a temperature range from -0.1 to $20.2^{\circ} \mathrm{C}$ (Table 3). These ranges of temperature thresholds represent the variability in temperature associated with given life history events across latitudes and regions. They are of interest, as a narrow range suggests universal temperature thresholds of events while a broad range signals the opposite.

Temperature thresholds of flowering, seed maturation and emergence of seedlings also tended to decline along the latitude gradient, so that the events occurred at lower temperature for northern as opposed to southern eelgrass populations (Fig. 4). This was the case for the temperature at the peak and end of the flowering period (Fig. 4c,e), the temperature at the peak of occurrence of mature seeds (Fig. 4d) and the temperature at the emergence of seedlings (Fig. 4f, Table 4 ). On average, the monthly temperature associated with the peak and end of flowering declined by 0.42 and $0.58^{\circ} \mathrm{C}$ for each degree increase in latitude, respectively. Similarly, the monthly temperature associated with the peak of seed maturation and the emergence of seedlings declined by 0.21 and $0.32^{\circ} \mathrm{C}$ for each degree increase in latitude, respectively (Table 4 ). The relationships were strongest for the temperature associated with the peak and the end of flowering, explaining $48-50 \%$ of these variables (Table 4 ).

In parallel, not surprisingly, the threshold photoperiod of flowering, seed maturation and emergence of seeds increased along the latitude gradient, so that the events occurred at a longer photoperiod for northern as opposed to southern eelgrass populations (see Fig. S1 in the Supplement at www. int-res.com/articles/suppl/m590p079_supp.pdf). The range in photoperiod associated with the events was narrow, however, especially for the peak in seed formation for which associated photoperiod ranged between 11.9 and $14.6 \mathrm{~h}$ across all latitudes (Table S1 in the Supplement). The relationships were significant for the photoperiod associated with the start and peak of flowering (Fig. S1a,c), the peak of mature seed formation (Fig. S1d) and the start of seedling emergence (Fig. S1f, Table S2). On average, the photoperiod associated with the start and peak of flowering increased by 15 and $5 \mathrm{~min}^{-1}$ for each degree increase in latitude, respectively, while the photo- 

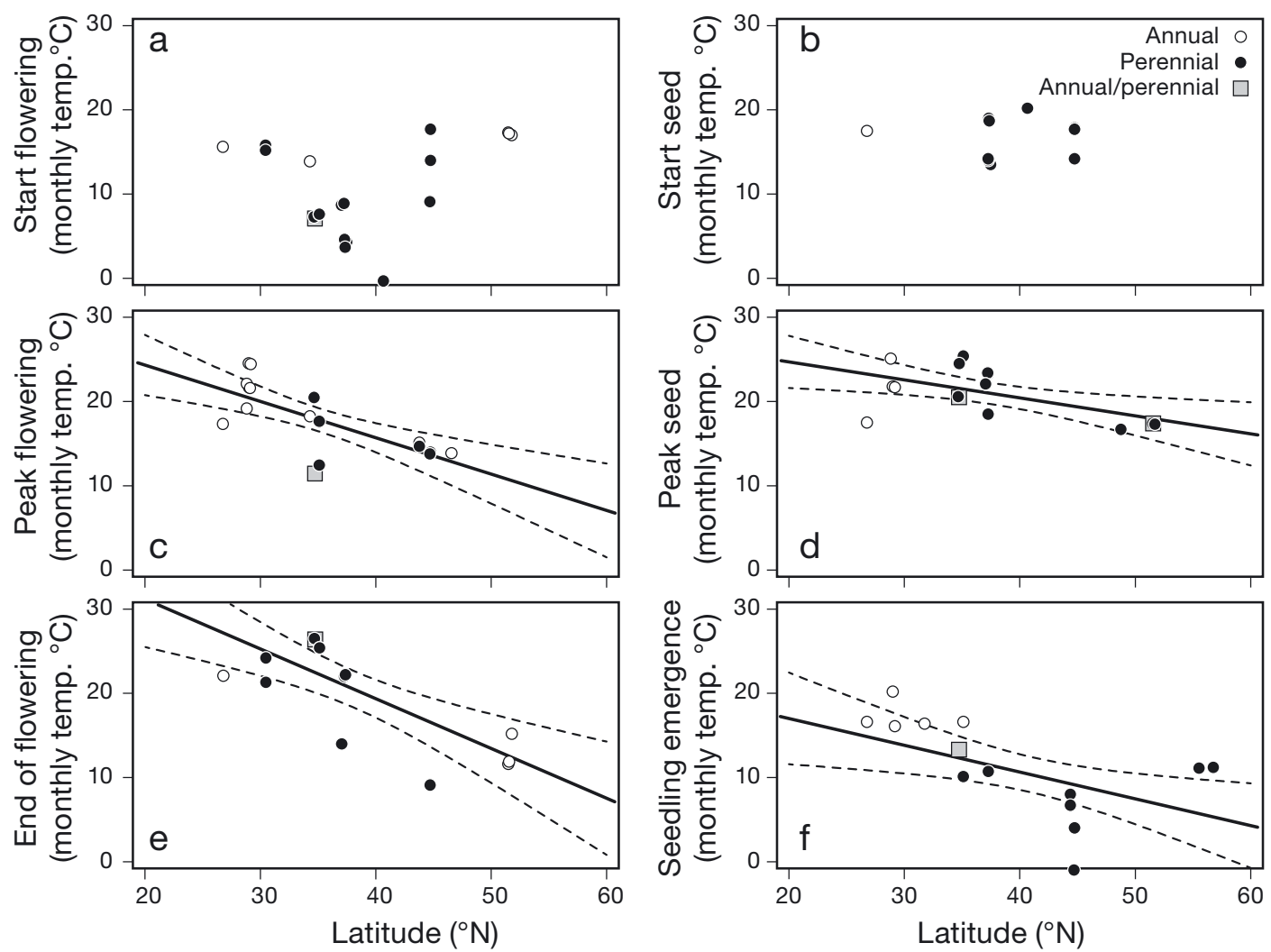

Fig. 4. Mean monthly temperature associated with the occurrence of various life history events of Zostera marina as a function of latitude of the population. The life history events are: (a) start, (c) peak and (e) end of the flowering period, and (b) start and (d) peak of mature seed formation and (f) emergence of seedlings. Other details as in Fig. 2

period of peak seed formation and start of seedling emergence increased by 4 and $6 \mathrm{~min}^{-1}$, respectively, for each degree increase in latitude. By contrast, the photoperiod associated with the end of flowering and the start of seed formation showed no significant relationship with latitude (Table S2).

Table 4. Relationships between the average air temperature $\left({ }^{\circ} \mathrm{C}\right)$ of the month associated with the various life history events and latitude $\left({ }^{\circ} \mathrm{N}\right)$ of the studied Zostera marina populations. For each dependent variable, the estimated slope of the regression line with latitude is shown with standard error (SE) and coefficient of determination $\left(\mathrm{R}^{2}\right)$. Number of observations (n) is given in Table 3. Significance levels: ${ }^{*} p<0.05$,

$$
{ }^{* *} \mathrm{p}<0.01,{ }^{* * *} \mathrm{p}<0.001
$$

\begin{tabular}{|lccc|}
\hline Dependent variable & Estimate & SE & $\mathrm{R}^{2}$ \\
\hline Monthly temperature associated with: & & \\
Start of flowering period & 0.284 & 0.155 & 0.089 \\
Peak of flowering period & $-0.424^{* * *}$ & 0.101 & 0.479 \\
End of flowering period & $-0.583^{* *}$ & 0.147 & 0.497 \\
Start of mature seed formation & 0.020 & 0.144 & 0.108 \\
Peak of mature seed formation & $-0.213^{*}$ & 0.074 & 0.310 \\
Start of seedling emergence & $-0.318^{*}$ & 0.114 & 0.263 \\
\hline
\end{tabular}

\section{DISCUSSION}

\section{Changes in eelgrass phenology along gradients in latitude and temperature}

Our study shows that the timing of life history events of Zostera marina changes along gradients of latitude and temperature and is generally delayed at northern colder locations relative to southern warmer locations. Hence, the start and the peak of the flowering period and of seed maturation occur earlier in the southern, warmer areas and later in the northern, colder areas. A similar pattern was found for seedling emergence, which occurred during the autumn in warmer areas and during spring in colder areas. The dataset did not include sufficient combined datasets on seed ripening and seedling emergence to evaluate the time elapsed between these events and whether this also shows a latitudinal trend. However, the slightly steeper slope of the relationship between 'start of seedling emergence' and latitude compared to the slope between 'peak of mature seed formation' and latitude suggests that the period from seed 
ripening to seedling emergence increases towards the north.

Mean annual temperature was generally a superior predictor of the timing of eelgrass life history events than was latitude, as relationships with mean annual temperature exhibited the highest coefficient of determination $\left(\mathrm{R}^{2}\right)$. This is likely because eelgrass at a given latitude represents a variety of growth conditions both with respect to temperature, which e.g. is higher for a given latitude on the Gulf Streaminfluenced west coast of Europe relative to the Atlantic coast of North America, but also with respect to other factors such as salinity that may also affect eelgrass reproduction (Phillips et al. 1983a).

Overall, our results of a general delay in reproductive phenology from south to north are in line with an earlier comparison of the successive development in flowering stages in eelgrass populations along the coasts of North America (Phillips et al. 1983b, Silberhorn et al. 1983). Our study extends these findings to the entire distribution area of eelgrass from where we could find seasonal studies in phenology, i.e. from 26.8 to $56.8^{\circ} \mathrm{N}$ and also identified temperature as a main predictor of this relationship. The findings likely extend even further north to subarctic and Arctic eelgrass populations near the northern distribution limit where flowering eelgrass has been observed, e.g. in late August in subarctic Greenland waters $\left(64^{\circ} \mathrm{N}\right)$ at water temperatures of $13-15^{\circ} \mathrm{C}$ (Olesen et al. 2015), and in northern Norway $\left(69.2^{\circ} \mathrm{N}\right.$ ) at $9^{\circ} \mathrm{C}$ (Olsen et al. 2013). However, a lack of seasonal observations from the Artic prevented an evaluation of life history timing of eelgrass at the northern limit. For eelgrass populations at $64^{\circ} \mathrm{N}$ in Greenland, a high degree of clonality as well as a general lack of seedlings suggest that the temperature increase in the period preceding a given event, i.e. degree days, is just at the lower limit for completing the reproductive cycle and may set the northern distribution limit (Olesen et al. 2015). For eelgrass, reproductive shoots develop from vegetative shoots (Setchell 1929), and a close coupling between reproductive and vegetative growth is therefore likely. As temperature is a main driver of metabolic processes including plant growth and development (Brown et al. 2004), the low temperatures in the north should delay the timing of individual events as well as the completion of the reproductive cycle. Indeed, species distribution models (generally encompassing terrestrial plants) show that the northern limit of species' ranges appears to be determined mainly by the inability to undergo full fruit maturation, while the southern limit appears to be caused by the lack of chilling temperatures that are necessary to break bud dormancy. Hence phenology is a key adaptive trait in shaping species distribution (Chuine 2010).

Latitude and temperature also affect the seasonality in eelgrass standing biomass, with earlier onset of seasonal biomass increase and peak biomass in warmer and southern areas compared to cold areas at higher latitudes (Clausen et al. 2014). However, the study by Clausen et al. (2014) indicated smaller shifts in the timing of the start of the growing season and the peak biomass ( $2-3 \mathrm{~d}$ per $1^{\circ}$ latitude) across latitudes than for start and peak of the flowering period ( $6-7 \mathrm{~d}$ per $1^{\circ}$ latitude) found here. This suggests that sexual reproduction is more responsive to latitudinal climatic variation than seasonal biomass development. The current study suggests that the length of the flowering season decreases with $3.7 \mathrm{~d}$ per $1^{\circ}$ latitude northwards and also tends to be shorter at lower annual temperatures. Hence, seed formation in northern populations may be restricted by lower temperatures that slow the rate of development and by shorter growing seasons that reduce the time for development of reproductive shoots and maturation of seeds. Seed maturation also occurred later in the season in colder, more northern populations (Fig. 3), which is in line with earlier findings showing that seeds are released from reproductive shoots much later (4-5 mo) in central compared to southern populations within the distribution range (Orth et al. 2000).

The timing of seedling emergence was closely coupled to gradients in latitude and temperature, suggesting that seeds from warmer, low-latitude populations germinate in autumn, whereas germination of seeds produced at higher latitudes is delayed until winter and early spring. Timing of seed germination and seedling establishment are critical, due to their strong vulnerability to environmental conditions (Marion \& Orth 2012, Infantes et al. 2016). Hence, seed dormancy during the harsh winters of northern latitudes may protect against germination when unfavourable conditions occur and seedling emergence is coordinated with the beginning of the growth season return of light in the spring as suggested for terrestrial plants (Baskin \& Baskin 2014). At warmer, lower latitudes, optimal conditions occur after the hot summer, and germination seems to be stimulated when temperatures cool in autumn (Moore et al. 1993). However, processes involved in the transition from seeds to seedlings are poorly understood even though these early life stages often are major bottlenecks in eelgrass recovery, and represent key information for restoration and conservation strategies. 


\section{Other factors potentially influencing eelgrass phenology}

Although temperature is a strong predictor of the timing of life history events, other variables could also be of importance and may contribute to explaining the variability at given temperature settings. Water depth and light attenuation may delay the duration and the timing of start and peak of flowering (Jacobs \& Pierson 1981, Olesen et al. 2017). Other local factors such as salinity may also affect germination success, with reduced salinity stimulating and advancing the emergence of seedlings (Phillips et al. 1983a, Pan et al. 2011). The timing of the end of the flowering season was, in particular, unrelated to latitude and temperature, suggesting that other drivers obscure the effect of climatic factors. For example, light attenuation may shorten the duration of the flowering season of eelgrass (Palacios \& Zimmerman 2007), and it is possible that nutrient-induced shading by opportunistic macroalgae, epiphytes or phytoplankton may exert a similar effect.

\section{Temperature thresholds of life history events}

The delay in the timing of life history events towards the north could be due to the same universal threshold temperature of events occurring later in the year further north, or it could represent a change in the threshold temperatures across latitudes. Universal temperature thresholds for stages in flower development were found across the latitude gradient $35-44^{\circ} \mathrm{N}$ along the Atlantic coast of North America (Silberhorn et al. 1983). However, our study demonstrates that such universal threshold temperatures cannot be extended across the distribution range of eelgrass. Rather, our study indicates that temperature thresholds of peak flowering, seed maturation and emergence of seedlings decrease along the latitudinal gradient, suggesting that such thresholds are subject to local adaptation or caused by a degree of phenotypic plasticity (Badeck et al. 2004, Winters et al. 2011, Jueterbock et al. 2016, Reusch 2014). This was particularly conspicuous for the emergence of seedlings for which the threshold temperature ranged over $21^{\circ} \mathrm{C}$ and, on average, declined by $0.3^{\circ} \mathrm{C}$ for each degree increase in latitude. Temperature has a strong influence on the timing and rate of seed germination, and laboratory studies indicate thermal optimum ranges of $6-11$ or $10-15^{\circ} \mathrm{C}$ for seeds originating from latitudes of 50 and $35^{\circ} \mathrm{N}$, respectively (Probert \& Brenchley 1999, Abe et al. 2008).
Germination is depressed or can be prevented at high temperatures (McMillan 1983), which probably plays a role in the timing of seedling emergence in warm-water populations, where autumn germination occurs as water temperatures decline below $15^{\circ} \mathrm{C}$ (Moore et al. 1993). In cold-water populations, where the main period of seedling appearance occurs in spring, seeds seem to require a cold winter period to induce peak germination because these seeds experience similar temperatures in autumn as in spring but they do not germinate in autumn (Keddy \& Patriquin 1978, Robertson \& Mann 1984, Valdemarsen et al. 2010). Whether this difference in temperature requirement across the latitudinal gradient is caused by genetic differentiation or by environmental conditions such as day length or temperature during which seeds are matured and dispersed remains to be tested. The response to seasonal temperature changes is not always clear, however, as seedlings may appear outside the period of maximum germination, although in low numbers, and environmental factors such as sediment organic content, oxygen conditions and seed burial depth also play a role in inducing seed germination (Moore et al. 1993, Probert \& Brenchley 1999, Jarvis \& Moore 2015).

The threshold temperature for maturation of seeds was the most temperature-specific and heat-requiring phase of the reproductive cycle (Table 3), suggesting that seed maturation may represent the bottleneck setting the northern limit of successful reproduction. However, mature seeds can be carried by floating reproductive shoots over long distances, thereby potentially enabling new populations to establish beyond the northern limit of in situ seed maturation (Harwell \& Orth 2002, Kendrick et al. 2012).

The temperature thresholds of life history events identified here on the basis of air temperatures may diverge somewhat from water temperature thresholds, which may generally be slightly lower, but this would not affect the identified trends and relative differences in temperature specificity between life history events. For more precise estimates of threshold temperatures, the best way would be to use common garden experiments to assess phenological responses to temperature of eelgrass distributed along a latitudinal gradient or to monitor water temperatures in the canopy at a wide selection of sites along with frequent observations of the populations to precisely identify the timing of each reproductive event. Such an experiment would require a coordinated effort in a large-scale international collaboration. So far, the current compilation represents the most com- 
prehensive overview of seasonality in eelgrass life history events across the species' distribution area.

While we also observed that the events in many cases occurred at a longer photoperiod further north, we interpret potential thresholds in photoperiod as being less important than temperature thresholds for the timing of events, as there is no support for such a relationship in the seagrass literature. For example, light does not seem to affect the seed germination process in eelgrass (Hootsmans et al. 1987, Moore et al. 1993). The observation of earlier flowering on the warmer east coast of the USA compared to the colder west coast at the same latitude also indicates a larger relative importance of temperature vs. photoperiod in controlling eelgrass phenology (Phillips et al. 1983b). Similarly, in the current data set, the formation of reproductive shoots is initiated earlier in the warmer Chesapeake Bay at $37^{\circ} \mathrm{N}$ than at the colder China coast at the same latitude.

\section{Space for time}

Using a space-for-time approach, findings from this study can help predict changes in reproductive strategies of eelgrass in response to climate warming. As higher temperatures were found to overall stimulate and advance eelgrass life history events, the slope estimates of the identified regression lines of the timing of a given reproductive stage versus temperature can serve as an indicator of how these life history events may respond to an increase in temperature. The start of flowering is, for example, predicted to occur $12 \mathrm{~d}$ earlier with a temperature increase of just $1^{\circ} \mathrm{C}$. Overall, an increase in temperature is predicted to shift eelgrass distribution northwards by stimulating sexual reproduction given that other habitat requirements, e.g. in terms of light and nutrient conditions, remain suitable (Kaldy \& Lee 2007). While a temperature increase is likely to stimulate northern populations, the southernmost populations probably already occur at their high-temperature limit so that a temperature rise would cause negative impacts due to heat stress, which can increase shoot mortality (Nejrup \& Pedersen 2008, Bergmann et al. 2010) and probably hamper flowering (Cabaço \& Santos 2012).

As populations differ in their tolerance to stress (Bergmann et al. 2010, Salo et al. 2014), which may reflect genetic differences or acclimative responses, space-for-time substitution should be used with caution to predict responses to climate change. For terrestrial plants, there is ample evidence that warming speeds up development and leads to earlier shifts to the next phenological stage (Badeck et al. 2004). However, a lack of time series implies very limited evidence of whether responses of marine plants to warming are plastic or adaptive, and a recent review therefore addresses the potential for adaptive responses, as evaluated from space-for-time studies, rather than solid evidence (Reusch 2014). For Zostera marina, common garden experiments suggest that local adaptation of the photophysiology to prevailing temperature regimes is possible (Winters et al. 2011). This is supported by a larger heat tolerance of southern Z. marina populations being linked with transcriptomic resilience, which is lacking in more northern populations (Franssen et al. 2011, Winters et al. 2011, Jueterbock et al. 2016). For the fresh/brackish Potamogeton pectinatus, reciprocal transplantations across latitude gradients indicated a compressed life cycle in northern populations, which may reflect local adaptation to a sub-arctic climate (Santamaría et al. 2003). For Z. marina, there is no evidence of how much the latitudinal trends in reproductive timing are caused by adaptive differentiations among populations. If phenological changes along climate gradients represent adaptation rather than acclimation, ample time may be needed for the plants to adjust to climate change. Also, low genetic diversity and reduced sexual reproduction suggest lower adaptive potential at the species' geographical limits compared to central populations (Olsen et al. 2013, Reusch 2014).

\section{CONCLUSIONS}

This study suggests a strong influence of latitude and temperature on the timing of life history events of eelgrass populations, which can help predict future eelgrass distribution patterns in response to global temperature rise (Chuine 2010). The severity of climate change impact on reproductive timing, however, depends on the extent to which the observed latitudinal changes are due to plastic responses to local temperature regimes or adaptive differentiation among populations.

Acknowledgements. The study received financial support from the NOVAGRASS project (0603- 00003DSF) funded by the former Danish Council for Strategic Research and was conducted in cooperation with the University of Amsterdam. We thank Ane Kjeldgaard and Peder Klith Bøcher for their help in creating Fig. 1 and for extracting the temperature data from the Worldclim database. 


\section{LITERATURE CITED}

Abe M, Kurashima A, Maegawa M (2008) Temperature requirements for seed germination and seedling growth of Zostera marina from central Japan. Fish Sci 74:589-593

Badeck FW, Bondeau A, Bottcher K, Doktor D, Lucht W, Schaber J, Sitch S (2004) Responses of spring phenology to climate change. New Phytol 162:295-309

Baskin CC, Baskin JM (2014) Seeds. Academic Press, New York, NY

Bergmann N, Winters G, Rauch G, Eizaguirre C and others (2010) Population-specificity of heat stress gene induction in northern and southern eelorass Zostera marina populations under simulated global warming. Mol Ecol 19:2870-2883

Boese BL, Kaldy JE, Clinton PJ, Eldridge PM, Folger CL (2009) Recolonization of intertidal Zostera marina L. (eelgrass) following experimental shoot removal. J Exp Mar Biol Ecol 374:69-77

Brown JH, Gillooly JF, Allen AP, Savage VM, West GB (2004) Toward a metabolic theory of ecology. Ecology 85: 1771-1789

Cabaço S, Santos R (2012) Seagrass reproductive effort as an ecological indicator of disturbance. Ecol Indic 23: 116-122

Cabello-Pasini A, Lara-Turrent C, Zimmerman RC (2002) Effect of storms on photosynthesis, carbohydrate content and survival of eelgrass populations from a coastal lagoon and the adjacent open ocean. Aquat Bot 74:149-164

Cabello-Pasini A, Muñiz-Salazar R, Ward DH (2003) Annual variations of biomass and photosynthesis in Zostera marina at its southern end of distribution in the North Pacific. Aquat Bot 76:31-47

Chuine I (2010) Why does phenology drive species distribution? Philos Trans R Soc B 365:3149-3160

* Churchill CA, Riner MI (1978) Anthesis and seed production in Zostera marina L. from Great South Bay, New York, USA. Aquat Bot 4:83-93

Clausen KK, Krause-Jensen D, Olesen B, Marbà N (2014) Seasonality of eelgrass biomass across gradients in temperature and latitude. Mar Ecol Prog Ser 506:71-85

de Cock AWAM (1981) Development of the flowering shoot of Zostera marina L. under controlled conditions in comparison to the development in two different natural habitats in the Netherlands. Aquat Bot 10:99-113

Den Hartog C (1970) The seagrasses of the world. NorthHolland Publishing Company, Amsterdam

* Duarte CM, Losada IJ, Hendriks IE, Mazarrasa I, Marbà N (2013) The role of coastal plant communities for climate change mitigation and adaptation. Nat Clim Chang 3: 961-968

Ferber S, Reusch TBH, Stam WT, Olsen JL (2008) Characterization of single nucleotide polymorphism markers for eelgrass (Zostera marina). Mol Ecol Resour 8:1429-1435

Forrest J, Miller-Rushing AJ (2010) Toward a synthetic understanding of the role of phenology in ecology and evolution. Philos Trans R Soc B 365:3101-3112

Franssen SU, Gu J, Bergmann N, Winters G and others (2011) Transcriptomic resilience to global warming in the seagrass Zostera marina, a marine foundation species. Proc Natl Acad Sci USA 108:19276-19281

Gagnon PS, Vadas RL, Burdick DB, May B (1980) Genetic identity of annual and perennial forms of Zostera marina L. Aquat Bot 8:157-162

Greve TM, Krause-Jensen D, Rasmussen MB, Christensen
PB (2005) Means of rapid eelgrass (Zostera marina L.) recolonisation in former dieback areas. Aquat Bot 82: 143-156

Gutiérrez JL, Jones CG, Byers JE, Arkema KK and others (2011) Physical ecosystem engineers and the functioning of estuaries and coasts. Treatise Estuar Coast Sci 7:53-81

* Harwell MC, Orth RJ (2002) Long-distance dispersal potential in a marine macrophyte. Ecology 83:3319-3330

* Hijmans RJ, Cameron SE, Parra JL, Jones PG, Jarvis A (2005) Very high resolution interpolated climate surfaces for global land areas. Int J Climatol 25:1965-1978

*Hootsmans MJM, Vermaat JE, Van Vierssen W (1987) Seedbank development, germination and early seedling survival of two seagrass species from The Netherlands: Zostera marina L. and Zostera noltii hornem. Aquat Bot 28:275-285

*Hut RA, Paolucci S, Dor R, Kyriacou P, Daan S (2013) Latitudinal clines: an evolutionary view on biological rhythms. Proc R Soc B 280:20130433

* Infantes E, Crouzy C, Moksnes PO (2016) Seed predation by the shore crab Carcinus maenas: a positive feedback preventing eelgrass recovery? PLOS ONE 11: e0168128

Jacobs RPWM, Pierson ES (1981) Phenology of reproductive shoots of eelgrass, Zostera marina L., at Roscoff (France). Aquat Bot 10:45-60

Jarvis JC, Moore KA (2015) Effects of seed source, sediment type, and burial depth on mixed-annual and perennial Zostera marina L. seed germination and seedling establishment. Estuaries Coasts 38:964-978

Jarvis JC, Moore KA, Kenworthy WJ (2012) Characterization and ecological implication of eelgrass life history strategies near the species' southern limit in the western North Atlantic. Mar Ecol Prog Ser 444:43-56

Johnson AJ, Moore KA, Orth RJ (2017) The influence of resource availability on flowering intensity in Zostera marina (L.). J Exp Mar Biol Ecol 490:13-22

Jueterbock A, Franssen SU, Bergmann N, Gu J and others (2016) Phylogeographic differentiation versus transcriptomic adaptation to warm temperatures in Zostera marina, a globally important seagrass. Mol Ecol 25: 5396-5411

Kaldy JE, Lee K (2007) Factors controlling Zostera marina L. growth in the eastern and western Pacific Ocean: comparisons between Korea and Oregon, USA. Aquat Bot 87: 116-126

Keddy CJ (1987) Reproduction of annual eelgrass: variation among habitats and comparison with perennial eelgrass (Zostera marina L.). Aquat Bot 27:243-256

Keddy CJ, Patriquin DG (1978) An annual form of eelgrass in Nova Scotia. Aquat Bot 5:163-170

Kendrick GA, Waycott M, Carruthers TJB, Cambridge ML and others (2012) The central role of dispersal in the maintenance and persistence of seagrass populations. Bioscience 62:56-65

K Kim SH, Kim JH, Park SR, Lee KS (2014) Annual and perennial life history strategies of Zostera marina populations under different light regimes. Mar Ecol Prog Ser 509: $1-13$

Lee KS, Park SR, Kim YK (2007a) Effects of irradiance, temperature, and nutrients on growth dynamics of seagrasses: a review. J Exp Mar Biol Ecol 350:144-175

Lee KS, Park JI, Kim YK, Park SR, Kim JH (2007b) Recolonization of Zostera marina following destruction caused by a red tide algal bloom: the role of new shoot recruitment from seed banks. Mar Ecol Prog Ser 342:105-115 
Lee SY, Kim JB, Lee SM (2006) Temporal dynamics of subtidal Zostera marina and intertidal Zostera japonica on the southern coast of Korea. Mar Ecol 27:133-144

* Marion SR, Orth RJ (2012) Seedling establishment in eelgrass: seed burial effects on winter losses of developing seedlings. Mar Ecol Prog Ser 448:197-207

McMillan C (1983) Seed germination for an annual form of Zostera marina from the sea of Cortez, Mexico. Aquat Bot 16:105-110

Meling-López AE, Ibarra-Obando SE (1999) Annual life cycles of two Zostera marina L. populations in the Gulf of California: contrasts in seasonality and reproductive effort. Aquat Bot 65:59-69

Moore KA, Short FT (2006) Zostera: biology, ecology and management. In: Larkum $\mathrm{T}$, Orth R, Duarte CM (eds) Seagrasses: biology, ecology and conservation. Springer, Dordrecht p 361-386

Moore KA, Orth RJ, Nowak JF (1993) Environmental regulation of seed germination in Zostera marina L. (eelgrass) in Chesapeake Bay: effects of light, oxygen and sediment burial. Aquat Bot 45:79-91

* Morita T, Okumura H, Abe M, Kurashima A, Maegawa M (2007) Density and distribution of seeds in bottom sediments in Zostera marina beds in Ago Bay, central Japan. Aquat Bot 87:38-42

Nejrup LB, Pedersen MF (2008) Effects of salinity and water temperature on the ecological performance of Zostera marina. Aquat Bot 88:239-246

Olesen B (1999) Reproduction in Danish eelgrass (Zostera marina L.) stands: size-dependence and biomass partitioning. Aquat Bot 65:209-219

* Olesen B, Sand-Jensen K (1994a) Patch dynamics of eelgrass Zostera marina. Mar Ecol Prog Ser 106:147-156

* Olesen B, Sand-Jensen K (1994b) Demography of shallow eelgrass (Zostera marina) populations - shoot dynamics and biomass development. J Ecol 82:379-390

* Olesen B, Krause-Jensen D, Marbà N, Christensen PB (2015) Eelgrass Zostera marina in subarctic Greenland: dense meadows with slow biomass turnover in cold waters. Mar Ecol Prog Ser 518:107-121

* Olesen B, Krause-Jensen D, Christensen PB (2017) Depthrelated changes in reproductive strategy of a coldtemperate Zostera marina meadow. Estuaries Coasts 40: 553-563

Olsen JL, Coyer JA, Stam WT, Moy FE, Christie H, Jørgensen NM (2013) Eelgrass Zostera marina populations in northern Norwegian fjords are genetically isolated and diverse. Mar Ecol Prog Ser 486:121-132

Olsen JL, Rouzé P, Verhelst B, Lin YC and others (2016) The genome of the seagrass Zostera marina reveals angiosperm adaptation to the sea. Nature 530:331-335

* Orth RJ, Moore KA (1983) Seed germination and seedling growth of Zostera marina L. (eelgrass) in the Chesapeake Bay. Aquat Bot 15:117-131

* Orth RJ, Harwell MC, Bailey EM, Bartholomew A and others (2000) A review of issues in seagrass seed dormancy and germination: implications for conservation and restoration. Mar Ecol Prog Ser 200:277-288

Palacios SL, Zimmerman RC (2007) Response of eelgrass Zostera marina to $\mathrm{CO}_{2}$ enrichment: possible impacts of climate change and potential for remediation of coastal habitats. Mar Ecol Prog Ser 344:1-13

Pan J, Xin J, Xiaojie LI, Yizhou C and others (2011) Influence of temperature and salinity on germination of eelgrass (Zostera marina L. ) seeds. J Ocean Univ China 10:147-152
Pan J, Han H, Jiang X, Zhang W and others (2012) Desiccation, moisture content and germination of Zostera marina L. seed. Restor Ecol 20:311-314

Park JI, Lee KS (2007) Effects of the Loess coating on seed germination and seedling growths of the eelgrass, Zostera marina. Algae 22:141-146

*Phillips RC, Backman TW (1983) Phenology and reproductive biology of eelgrass (Zostera marina L.) at Bahia Kino, sea of Cortez, Mexico. Aquat Bot 17:85-90

*Phillips RC, Stewart GW, McRoy P (1983a) Reproductive strategies of eelgrass (Zostera marina L.). Aquat Bot 16: $1-20$

* Phillips RC, McMillan C, Bridges KW (1983b) Phenology of eelgrass, Zostera marina L., along latitudinal gradients in North America. Aquat Bot 15:145-156

*Poumian-Tapia M, Ibarra-Obando SE (1999) Demography and biomass of the seagrass Zostera marina in a Mexican coastal lagoon. Estuaries 22:837-847

* Probert RJ, Brenchley JL (1999) The effect of environmental factors on field and laboratory germination in a population of Zostera marina L. from southern England. Seed Sci Res 9:331-339

Reusch TB (2014) Climate change in the oceans: evolutionary versus phenotypically plastic responses of marine animals and plants. Evol Appl 7:104-122

Robertson AI, Mann KH (1984) Disturbance by ice and lifehistory adaptations of the seagrass Zostera marina. Mar Biol 80:131-141

Salo T, Pedersen MF, Boström C (2014) Population specific salinity tolerance in eelgrass (Zostera marina). J Exp Mar Biol Ecol 461:425-429

* Santamaría L, Figuerola J, Pilon JJ, Mjelde M and others (2003) Plant performance across latitude: the role of plasticity and local adaptation in an aquatic plant. Ecology 84:2454-2461

* Santamaría-Gallegos NA, Sánchez-Lizaso JL, Félix-Pico EF (2000) Phenology and growth cycle of annual subtidal eelgrass in a subtropical locality. Aquat Bot 66:329-339

Setchell WA (1929) Morphological and phenological notes on Zostera marina L. Univ Calif Publ Bot 14:389-452

* Silberhorn GM, Orth RJ, Moore KA (1983) Anthesis and seed production in Zostera marina L. (eelgrass) from the Chesapeake Bay. Aquat Bot 15:133-144

*Valdemarsen T, Canal-Vergés P, Kristensen E, Holmer M, Kristiansen MD, Flindt MR (2010) Vulnerability of Zostera marina seedlings to physical stress. Mar Ecol Prog Ser 418:119-130

*Van Lent F, Verschnure JM (1995) Comparative study on populations of Zostera marina L. (eelgrass): experimental germination and growth. J Exp Mar Biol Ecol 185:77-91

*Van Lent F, Verschuure JM (1994) Intraspecific variability of Zostera marina L. (eelgrass) in the estuaries and lagoons of the southwestern Netherlands. I. Population dynamics. Aquat Bot 48:31-58

Van Tussenbroek BI, Márquez-Guzman J, Wong R (2009) Phenology of marine angiosperms (seagrasses): reproductive synchrony in the sea. In: Gamboa-deBuen A, OrozcoSegovia A, Cruz-Garcia F (eds) Functional diversity of plant reproduction. Research Signpost, Kerala, p 17-46

*Van Wynsberge S, Menkes C, Le Gendre R, Passfield T, Andréfouët S (2017) Are sea surface temperature satellite measurements reliable proxies of lagoon temperature in the South Pacific? Estuar Coast Shelf Sci 199: $117-124$

Walker DI, Olesen B, Phillips RC (2001) Reproduction and 
phenology in seagrasses. In: Short FT, Coles RG (eds) Global seagrass research methods. Elsevier Science BV, Amsterdam, p 59-78

Wang M, Wang Y, Guo X, Sha J, Zhang H, Tang X, Zhou B (2016) Reproductive properties of Zostera marina and effects of sediment type and burial depth on seed germination and seedling establishment. Aquat Bot 134:68-74

Winters G, Nelle P, Fricke B, Rauch G, Reusch TBH (2011) Effects of a simulated heat wave on photophysiology and

Editorial responsibility: Morten Pedersen,

Roskilde, Denmark gene expression of high- and low-latitude populations of Zostera marina. Mar Ecol Prog Ser 435:83-95

Yamaki K, Ogawa H (2009) Characterization of germination and seedling production of Zostera marina and $Z$. caulescens. Coast Mar Sci 33:1-8

Z Zhang PD, Liu YS, Guo D, Li WT, Zhang Q (2016) Seasonal variation in growth, morphology, and reproduction of eelgrass Zostera marina on the eastern coast of the Shandong Peninsula, China. J Coast Res 318:315-322

Submitted: August 2, 2017; Accepted: January 6, 2018

Proofs received from author(s): February 19, 2018 